\title{
Running in French: A Question of Performance*
}

\author{
Aliénor Jeandidier \\ Université de Lyon \\ alienor.jeandidier@yahoo.fr \\ http://orcid.org/0000-0003-2420-0122
}

\begin{abstract}
Running entered the official French language dictionary in 2019. This paper proposes to focus on the motivations which have led to the acceptance of this Anglicism in French. Indeed, running has achieved the performance of being more than the mere activity of running: it is a whole phenomenon which has been gaining ground since the late 2000s, as communities, events and derived products have been flourishing. Supposedly, running must have been a buzzword in the field of sports. But given its lexicalization, running could not just remain a buzzword. It has become a whole concept as it contributes to feeding the field of running in French through both semantic extension and precision. It will be of interest to examine the pathway of the Anglicism running from a phenomenon creating the buzz to a widely accepted and frequently used lexeme in French. The question of linguistic performance will therefore be tackled, thanks to recent online data, in order to show how running has become important not only in the world and language of sports, but also in the standard everyday language in France.
\end{abstract}

Keywords: running, buzzword, language contact, performance, sports and everyday language

\section{Introduction}

Running is an Anglicism used in French belonging to the field of sports, borrowed from the English noun "running" which is recorded in the English dictionary as such and can be defined as the activity or sport of running. ${ }^{1}$ Running entered the official French Dictionary Le Petit Robert in 2019, with two definitions: 
Nom masculin : pratique régulière et intensive de la course à pied dans un esprit de compétition. (Masculine noun: regular and intensive practice of running in a competitive spirit. [My translation])

Nom féminin : chaussures de sport pour la course à pied. (Feminine noun: sports shoes for running. [My translation])

In the field of sports, the French course is also defined both as the action of running and as a struggle and competition of speed, as one can read in Le Petit Robert and Larousse dictionaries. Therefore, the Anglicism running and its French counterpart course seem to share similarity of context (sports) and similarity of meaning (running, competition, speed) - i.e. the very definition of synonyms (Rubenstein \& Goodenough, 1965: 627). Consequently, what distinguishes the Anglicism from the original French lexeme? In other words, the core question of this paper is: why has the Anglicism running been integrated into French despite the presence of a French lexeme referring to the same sports?

The distinction may lie in the fact that, metonymically, running in the French dictionary also designates the shoes used for this activity. The Anglicism thus appears to extend the definition around the activity of running by being polysemous. Hence, my first hypothesis is that running has been integrated because it presents more semantic possibilities. If this Anglicism has become a French lexeme, it is probably because it fills a gap which its French counterpart course missed.

Additionally, the presence of sports in the media has resulted in the language of sports becoming more significant (Taborek, 2012: 237). This has facilitated the spreading of running since the late 2000s, resulting in a whole world building around it (communities, events, derived products, etc.). It may be argued that running has created the buzz in France - that is to say, innovation and consequent excitement and enthusiasm around the activity of running. My second hypothesis thus states that running is a buzzword of English origin whose role is to embody sports performance. Performance is here understood in the way someone or something acts or behaves in order to be the best in a particular domain - something which is particularly soughtafter in sports. A buzzword is basically a fashionable word or expression meant to sound important and attract attention for a while before vanishing for excess of use. However, because of its recent integration into the dictionary, running has not disappeared from the French linguistic landscape. Therefore, how has the Anglicism running managed to achieve this linguistic performance?

This study aims to explore the motivations which have led to the acceptance of running in the official French language. It focuses on the French language in contemporary France. It adopts a sociolinguistic standpoint and a qualitative way of analyzing the data. The following section lays out linguistic background around borrowings and sports Anglicisms. A more thorough definition for buzzword will also be provided, before overviewing the main criteria leading to the integration of a word from a donor language to a recipient language. Section 3 will be devoted to the 
presentation of the methodology and database collected for this study. Finally, Section 4 will give an interpretation of the data to identify the criteria which have contributed to using and adopting the Anglicism running in French.

\section{Linguistic Background}

This section will provide the necessary linguistic context on Anglicisms- with a focus on the field of sports -, on the notion of "buzzword", and on the progression of a lexeme from a borrowed item to a lexicalized word in the dictionary.

\subsection{Borrowing from English: A thriving variety of Anglicisms}

Defining an Anglicism may seem simple as, generally speaking, it can be any word borrowed from the English language, and therefore of English appearance and/or origin. However, various studies have demonstrated that defining an Anglicism is not as simple. There are indeed recognizable lexical Anglicisms (Picone, 1996; Saugera, 2017), and more or less recognizable Anglicisms since the latter can be semantic, structural, graphological, phonetic (Colpron et al., 1998), not counting hybrids and false Anglicisms (Picone, 1996; Furiassi \& Gottlieb, 2015). Scholars have also distinguished the concept of pragmatic borrow

ing typical of some Anglicisms (Khoutyz, 2009; Andersen, 2014; Winter-Froemel, 2017). Gottlieb (2005: 163) says the term Anglicism is "an umbrella label for any sign of interference". Due to the variety of aspects Anglicisms may take, Gottlieb (2005: 163) thus identifies an Anglicism as "any individual or systemic language feature adapted or adopted from English, or inspired or boosted by English models, used in intralingual communication in a language other than English”. The Anglicism running in French belongs to the category of recognizable lexical Anglicisms.

At this juncture, it is worth introducing the notion of false Anglicism:

[A] false Anglicism (henceforth FA) is defined as a new lexical unit in a recipient language (RL) which has one of the two following defining features:

- it is homographic to an English lexeme and has acquired a different or additional sense in the RL (...)

- it is made up of a combination of English morphemes and/or lexemes, but has no established meaning in any native variety of English [...]. (Renner \& FernándezDomínguez in Furiassi \& Gottlieb, 2015: 148)

Renner and Fernández-Domínguez note that the canonical way to prove an Anglicism is false is to translate it into English. Let us check this for running. Consider the utterance "Le running est l'un des sports les plus pratiqués". It is perfectly English to say: "Running is one of the most popular sports", like "Football is one of the most popular sports". In English, the -ing suffix can turn the verb into a noun, either for contextual reasons (e.g. "Eating too fast will make you sick"), or because the noun has 
been lexicalized - which is the case for "running" in English. However, whereas one can say "Je vais faire un running" in French, it is impossible to say * "I'm going to do a running” in English (the correct form would be "I'm going out for a run"). Therefore, running can be more or less categorized as a false Anglicism, depending on its meaning in the utterance. Interestingly, running is similar to common false Anglicisms in French (e.g. parking < "parking lot", dressing < "dressing room", pressing < “dry cleaner"), because of the nominalizing -ing suffix typically used in French when it comes to borrowing from English (Picone, 1996: 356) - as if this suffix were already attesting to the Englishness of the word. Humbley (2007: 8-9) says of the -ing suffix construction that it is successful in French due to its capacity for borrowing from English while modifying the syntax and the semantics of the loanword.

Notwithstanding all their considerable forms, Anglicisms undeniably constitute a vivid source of borrowings from foreign languages, principally due to the growing influence of Anglo-American culture and of English as a world lingua franca since the second half of the $20^{\text {th }}$ century (Andersen, 2014: 17) - and ever more since the advent of World Wide Web in the nineties, thus providing "heavy lexical influence" and "potentially novel and deeper contact outcomes" (Saugera, 2017: 7). It is difficult to measure the number of Anglicisms permeating a foreign language, as only the ones that are officially integrated into specialized and general lexicons can be recorded. In France, according to an article published by the French national newspaper Le Monde in March 2019, the proportion of Anglicisms that have entered the last three dictionary editions since 2017 amounts to $16.6 \%$ of the total number of new lexicalized words given that nearly four new words out of ten are foreign borrowings, the other $22 \%$ coming from sixteen different languages. ${ }^{2}$ Also, lexicalized Anglicisms affect all fields of language, from specialized lexicons (e.g. computing: geek, tag, pop-up; fashion: tweed, trench, jean; sports: football, tennis, rugby) to standard everyday language (e.g. week-end, job, overdose) - sometimes with alterations to adapt to the French rules of construction (e.g. un jean with the dropping of the "s" plural form, as opposed to the English “a pair of jeans” or " $\varnothing$ jeans” because English takes the shape of the garment into account - two legs, justifying the plural). Anglicisms then account for a significant part in terms of borrowing in French. Considering that and all the other unmeasurable temporary Anglicisms, Chesley (2010) argues Anglicisms can be regarded as being a particular subset of borrowings endowed with flexibility and polysemy: they can easily change cultural and semantic context (e.g. pack from the rugby lexicon used to talk about a group of political negotiators in a press article). According to Chesley (2010), Anglicisms are a phenomenon of borrowing of their own.

According to Dubois et al. (2001: 177), “il y a emprunt linguistique quand un parler A utilise une unité ou un trait linguistique qui existait précédemment dans un parler B (dit langue source) et que A ne possédait pas ; l'unité ou le trait emprunté sont eux-mêmes qualifiés d'emprunts". ${ }^{3}$ Whether borrowing is necessary comes into question. Myers-Scotton (2002) makes a distinction between core borrowings (words which duplicate already existing words) and cultural borrowings (words for new nonlexicalized concepts). The former can be considered unnecessary as they are a kind of 
replication, whereas the latter can be deemed necessary to fill a lexical gap. In the same line, Rodríguez González's (1996) study considers the motivations leading to the use of Anglicisms in Spanish. Rodríguez González refers to Halliday's theory of functions in the semantic system of a language (1978): the "ideational, the "interpersonal", and the "textual" functions.

The "ideational" function basically corresponds to the thing a word refers to. Rodríguez González (1996: 110) applies it to the borrowings integrated at an early stage - i.e. those which fill a lexical gap in the recipient language (e.g. caddie in golf - for both Spanish and French).

The "interpersonal" function "is concerned with the use of linguistic units or structures that mark personal and social relations" - i.e. "words and expressions that are stylistically marked and have an emotive connotation” (Rodríguez González, 1996: 111). Concerning loanwords, the "interpersonal" function comes on stage as a way to highlight something which would not stand out with equivalents in the recipient language. This function applies to borrowings which are usually not integrated. Because these borrowings are “foreign”, they "are apt to develop an 'expressive' meaning” - e.g. contempt, irony, affectation (prestige), exaggeration, etc. (González Rodríguez, 1996: 112) - which would not be conveyed by the native equivalent. The following French utterance can be used to exemplify the "interpersonal" function: "dedans y a tout mon love”. ${ }^{4}$ This is a private Facebook publication accompanying a picture of a bag a godmother had manufactured herself for her godchild. Borrowing from English here fulfills stylistic purposes; love is somehow synonymous with its native counterpart amour, but with something more - probably stressing the time and heart she had devoted in making this present. The Anglicism love takes on a positive emotional connotation.

The "textual function" is "the function that language has of creating text, of relating itself to the context - to the situation and the preceding text" (Halliday, quoted by Rodríguez González, 1996: 116). According to Rodríguez González, when applied to borrowings, the "textual" function can include loanwords with both "ideational" and "interpersonal" functions, and reflects tendencies on the part of the author resorting to borrowing - aiming "to obtain a high degree of information, clarity and precision" (Rodríguez González, 1996: 116). In the case of Anglicisms, a tendency towards simplification, clarity and precision may be observed (Rodríguez González, 1996: 116). In my previous example, love is shorter than amour, expressing economy of language (one syllable), and as a corollary going straight to the point. Furthermore, Rodríguez González (1996: 117) argues that the textual function in borrowings can help avoid polysemous clashes. A French example would be "le Penelopegate": back during the 2017 presidential primaries, a candidate had to quit because his wife (Penelope) had been involved in political and financial fraud. Affixing the end of a well-known American political scandal (the Watergate) to the fallen candidate's wife's name not only contributes to making it sound shocking, but also avoids any ambiguity with the French scandale which can have a sexual connotation. 
Anglicisms used in the "interpersonal" and "textual" functions may not be deemed necessary as they do not fill a lexical gap in the native language. Nonetheless, they fill a semantic gap and are used stylistically to convey language effects that would not be possible with native counterparts. What about sports Anglicisms?

\subsection{Sports Anglicisms}

The language of sports can be regarded as a specialized language because of its specific vocabulary and rules. According to Cabré (1998: 119), specialized languages are linguistic codes different from the common language, consisting of rules and specific units: in this way, they are pragmatic sub-assemblies of the language in its broad sense, generally in inclusion relations, intersecting with the common language (Cabré, 1998: 126). Taborek (2012: 237) reckons there is a language of sports, existing since antiquity, and being “a rich area of specialist linguistic communication”. In this perspective, there is a specific terminology attached to the language of sports - which, as in any other specialized language, has the particularity of being monoreferential (Durieux, 1996: 89).

The proportion and necessity of borrowings may vary according to the specialized language field. In the case of sports, Anglicisms appear to structure the whole language (Bernard-Béziade \& Attali, 2012: 120): sports Anglicisms would then belong to the class of cultural borrowings (i.e. necessary), so would be monoreferential and linked to the "ideational" function.

Bernard-Béziade \& Attali (2012: 121) trace the origin of the word sport in French as being an Anglicism, itself a former old French borrowing desport $\left(12^{\text {th }}-13^{\text {th }}\right.$ century) - initially designating any type of amusement. In England, at the beginning of the $17^{\text {th }}$ century, people started betting on performances. A word was thence needed to express that new reality: sport was deemed appropriate. Its first attestation in English with its modern meaning dates back to 1812 (Herráez Pindado, 2009: 3). Sport came back to France in the second half of the $19^{\text {th }}$ century. This corresponds to the unprecedented development competitive sports enjoyed at that time, principally taking place in England (Defrance, 2011: 13). Herráez Pindado (2009: 2) observes most sports come from England. (e.g. football, rugby, rowing, tennis). Even the sports from other countries (e.g. judo) would undergo changes in their rules due to the strong leverage England exerted on the world of sports. Stated differently, England exported a model of physical play not only in the form of disciplines created home and spread internationally, but also by modifying the practice of the disciplines from abroad (Defrance, 2011: 14). This explains the correlated development of English sports language exporting elsewhere.

Bernard-Béziade \& Attali (2012: 122) note that when it comes to the language of sports, Anglicisms are characteristic, if not indispensable, elements to refer to realities related to sports (football, rugby, tennis, surf, golf, basketball, etc. concerning the very names of some sports; dribble, corner, set, ring, tee, etc., for some specific actions, phases, places, or objects), and in some way to be kinds of passwords shared in all 
countries so as to be able to play the sports and to compete with one another ${ }^{5}$ BernardBéziade \& Attali (2012: 122) quote Dauzat (1952) who suggested one of the reasons for the use and consequent entry of Anglicisms in French is their typical concision and rapidity - features which, to a certain extent, fit well with the field of sports. BernardBéziade \& Attali thus contend Anglicisms have been feeding the language of sports for decades, and they will probably continue doing so. In this perspective, Anglicisms are narrowly coupled with the language of sports in the same way as values and performances are associated with sports activities. Bernard-Béziade \& Attali (2012: 121) emphasize on the unique model offered by sports since the activities are codified and framed by rules, federations and competitions which take on an international scope, leaving but little space for language flexibility - and thus reinforcing English prevalence in this domain.

However, not all the words referring to sports are from English origin. The French sports lexicon is quite rich (e.g. alpinisme, athlétisme, course à pied, natation, etc.). La course or la course à pied is a discipline of its own, with many practitioners. So, how come the Anglicism running has been integrated into French? At first sight, running is a lexical borrowing, being integrally borrowed from the English "running". Lexical borrowings are the most obvious Anglicisms due to their complete English appearance - and supposedly semantic correspondence to the donor language's lemma. Chesley (2010: 233) recalls that a lexical borrowing is defined "as a lexical item (lemma) from a donor language satisfying the following criteria:

i. the (approximate) form and meaning are copied from donor to recipient language, without adaptation to French morphological and graphical conventions;

ii. the borrowing is not yet found in a particular French dictionary.

The form and meaning of running are apparently directly copied from the English lemma. Chesley's first criterion is met. However, the particularity of running is that it has just entered the 2019 French dictionary edition: it does not meet the second criterion stated by Chesley anymore. This Anglicism may not be necessary contrary to other sports Anglicisms. Therefore, one may logically wonder why running has eventually integrated the official French lexicon.

\subsection{From a Buzzword to a Lexicalized Item}

This subsection aims to understand the pathway of an Anglicism from a borrowed item to a lexicalized item. Assuming the focus of the present study is a buzzword, I will deal with the Anglicisms which are frequent to the point of being fashionable and thus regarded as buzzwords.

The word "buzzword" is originally a neologism forged by students from Harvard Business School in order to create shortcut phrases and keywords to refer to important notions (Hallgren \& Weiss, 1946: 263). The aim of a buzzword was to be a means through its shortness and consequent buzzing effect for the students to remember a 
concept. There were as many buzzwords as there were students and promotions in Harvard: buzzwords would then pop up and out accordingly. Over time, the lexeme "buzzword" entered the English dictionary ${ }^{6}$ in 1965, and it has since become the hypernym for trendy words fluctuating according to fashion and time - whatever the field of language. Contemporary dictionaries such as the Longman Dictionary of Contemporary English, the Cambridge Dictionary, the MacMillan Dictionary, and the Merriam-Webster insist on the voguish character of a buzzword, its sudden popularity, its attachment to a special area of knowledge, and its capacity for producing an effect. Buzzwords in the fields of business, fashion, sports, politics, or technology, are particularly thriving.

In French, there are many Anglicisms which can be considered buzzwords and which are more or less successful over a given period: swag, asap, amazing, story, battle, $O M G^{7}$, to quote but a few which have been in vogue for the past few years either among the young, the journalists, or any other category of people. All these words seem to have equivalents in French ${ }^{8}$ though, which does not necessarily justify their use after all - apart from the fashionable adding effect they may produce (Jeandidier, 2018). Where does this fashionable adding effect come from? The answer to this question probably lies in the age-old infatuation of French for Anglicisms (Saugera, 2017). As said earlier, the English language has benefited from an evergrowing popularity in many fields; no surprise it exerts attraction and consequent prestige on French, being considered chic and trendy:

Furthermore, it is also undeniable that in today's globalised world, English enjoys a particular prestige, and it seems that many a concept originating from American/English discourse is willingly adopted as a marker of 'updatedness', especially among the young, but not only among them. (Ben-Rafael, 2008: 64)

Such prestige may also lie in the very form of the English loanwords, as Furiassi puts it (2003: 121):

The steady success and popularity of English loanwords has been motivated largely by their own inherent appeal: English words have a strong sound and visual impact which make them easily trend-setting.

The use of Anglicisms is therefore significant: they contribute to the marking of a certain standpoint adopted by the speakers, privileging prestige over meaning. Indeed, as Anglicisms come from another language system, it may be difficult for some French speakers to clearly understand such words - even for the users themselves sometimes; this is notably the case for buzzwords of English origin (Jeandidier, 2018). Concerning the Anglicisms coexisting with French equivalents, the speakers also adopt a specific standpoint loaded with newness, trend and prestige, as Khoutyz (2009: 9) states:

The use of the borrowing often signifies the fact of shared knowledge and the existence of the connection between the previous local term and new, more fashionable and easy-to-use 
anglicisms. The speaker's choice of anglicisms illustrates their perception of the narration and their standpoint on the discussed topic.

Borrowing from English is thus done for pragmatic purposes, in order to adopt a certain point of view for a certain topic at a certain moment in specific circumstances. This is typical of buzzwords of English origin in French. The above-mentioned buzzwords of English origin, and probably all the others, are therefore necessarily linked to a given context in a given time and place, among given people. Consequently, a buzzword is not meant to live on, but to disappear with its attached concept, and to be replaced by another to designate either a similar concept or a new one. Considering that, a buzzword is not easy to appreciate as it is an unstable linguistic item - especially when it comes from a foreign language system (Jeandidier, 2018). In this perspective, buzzwords could be connected with slang. Slang is defined as follows:

Slang is an ever changing set of colloquial words and phrases that speakers use to establish or reinforce social identity or cohesiveness within a group or with a trend or fashion in society at large. (Eble, 1996: 11)

In a 2010 study, Fiévet and Podhorná-Polická explain how slang can spread rapidly among a given community. Their case study focuses on the lexeme bolos among French youngsters - to exemplify slang within a group - and the syntagm faire le buzz in the media - to illustrate how slang can become fashionable on a broad scale. Fiévet and Podhorná-Polická notice that bolos has found greater resonance among the interviewed set of the Paris banlieue youth mainly for attachment of identity to their everyday reality - drug dealing in front of their HLM housing - and also for the difficulty of tracing the etymology of the word, hence reinforcing its appropriation by the group using it (Fiévet \& Podhorná-Polická, 2010: 37). Concerning the phrase faire le buzz, Fiévet \& Podhorná-Polická note that it comes from media slang. Faire le buzz benefited from excessive media coverage especially at the end of 2009 (Fiévet \& Podhorná-Polická, 2010: 33). The authors predicted this phrase would sooner or later leave the sphere of media slang - which indeed happened since the Anglicism buzz eventually entered the French dictionary edition of 2010.

In some cases, buzzwords may therefore be completely adopted and lexicalized - which totally lies in contrast to what has just been said about the buzzwords' instability and dependence on circumstances. This is the case for buzz (2010), but also for hashtag, selfie (2015), and more recently like and liker (2019). These examples can be labelled buzzwords since they literally made the buzz when they appeared in French. ${ }^{9}$ A closer look reveals these former fashionable words were not really in competition with French equivalents as they expressed realities that did not exist before. Those realities were new at the time, hence provoking excessive craze. Buzz in French takes on the meaning of excitement created by an Internet phenomenon, and has been used in expressions such as faire le buzz, créer le buzz, gros buzz... for more than a decade now. Even if the hashtag symbol has its French equivalents mot-dièse or motclic, the Anglicism hashtag refers to the symbol which transforms a clickable link into a 
topic for discussion, and even now directly to the link opening to the discussion - a totally new concept when it appeared, and which became rapidly popular. A selfie is a photo of yourself in a special context you take with your smartphone, something which did not exist before the advent of smartphones and their incredible technological capacities: no wonder people massively want to capture precious moments at any time and in any circumstance. Finally, a like and its derived verb liker can only be used in media contexts, thus being different from the French aimer. All these Anglicisms have been integrated since they have shifted from a buzzword initially highly dependent on a specific semantic context and register, to a full lexical item which can be fully recognized and understood with no context in standard language.

The reasons for integrating these buzzwords of English origin into the dictionary follow the usual integration continuum. Greavu \& Zdrenghea (2010: 127) recall the definition of "integration" given by Hasselmo in 1970: "the habitualization through repetition of certain instances of interference from one language into another". This means that after a certain period of frequent usage, the loanword can be incorporated into a specific language. Grosjean (2001: 335) states:

A loanword is finally accepted when it is no longer treated differently from other words in the language and when dictionaries, national academies, and influential writers accept it. It is then a loan only in the historical sense.

Before that ultimate stage, various factors come into play. Greavu \& Zdrenghea (2010: 131) mention the different adaptations a borrowing may go through such as morphophonemic adaptation to the rules of the recipient language. A loan can remain adapted and finally disappear, or evolve to complete adoption and assimilation, especially thanks to sociocultural factors which play an important part in the criteria of integration (Greavu \& Zdrenghea, 2010: 128). These criteria of integration can be used by lexicographers to officially adopt a loanword - criteria such as usage, frequency, domain of language, register, word class, and the time elapsed between the apparition of the word and its full acceptance. Josselin-Leray and Roberts (2010: 1-2) particularly focus on lexical banalization, i.e. "le fait qu'un terme passe de la langue spécialisée à la langue non spécialisée (à la langue courante), phénomène dû à sa diffusion par divers interlocuteurs (dont les principaux représentants sont les médias)".${ }^{10}$ Four things come into play: the situation of communication in which the term is used, its lexical frequency and/or its significance in the area of use, the documentation used by the lexicographers, and the users' needs (Josselin-Leray \& Roberts, 2010: 2). Other processes can also be taken into consideration, such as metaphorization and morphology - including word class (nouns are often overrepresented), derivation (usually following the first-group construction such as in liker), length of the word (Béjoint, 1988: 362) notes "one-element words have more chances of being recorded than multi-element words"), and acronyms (Josselin-Leray \& Roberts, 2010).

Considering all these elements, the Anglicism running appears to be in keeping with some of the key criteria for a lexeme to be easily integrated. Indeed, running is a one-element noun; it seems to have crossed the border between specialized and non- 
specialized language since it has entered the common language dictionary; and obviously it has been used considerably enough for the lexicographers to adopt it.

\section{Data, methodology and results}

The present study intends to provide a qualitative analysis of the Anglicism running in French. Section 3 presents the database and methodology used to retrieve and interpret the data. The results are displayed in tables and figures for the sake of clarity.

\subsection{Presentation and analysis of the data collected from JSI Web Corpus 2014-2016}

First, I specifically explored the written corpus JSI Web Corpus 2014-2016 indexed in Sketch Engine. This corpus consists of various online French journalistic resources from French speaking countries over the period 2014-2016. After typing the first four letters of running followed by an asterisk (runn*), all the occurrences found were saved into an Excel document. It must be said that the data provided as such only contain the extracts in which the occurrences appear. I then proceeded to the elimination of the items which did not correspond to my object of study: utterances in English; film and song titles and references; proper names (at the exception of French running clubs and events, and of a few products which I believe participate in the integration of the lexeme running into the French language); lexemes containing running but used in other sports (running-back, ultra-runner, runner-up); and the fields of video games (a runner game), politics (running mate), show (running gag, running joke, show runner), business (runné, front running), and jobs (runners used to mean "couriers"). Also excluded from the study were occurrences appearing in strange sentences mixed with letters and symbols - probably because some data transferred to Excel had been damaged. All the occurrences which were not from French websites were also eliminated, but for Canadian, Belgian, Swiss, African and Lebanese websites - i.e. countries which use French as an official or vehicular language. I should also indicate that while sorting out some six thousand occurrences, a few might have been deleted inadvertently. Overall, the 2825 occurrences collected for this study should be sufficient to support analyses and conclusions.

The presentation of the data collected from JSI Web Corpus 2014-2016 is displayed in the next paragraphs and follow-up tables according to the origins of the websites and their nature, and according to the different meanings and declensions running has in French.

\subsubsection{Results according to websites}

Table 1 classifies the websites according to their origins. Tables 2 through 5 transcribe the numbers and percentages of the websites according to their nature, i.e. their appropriate fields of competence.

The share of websites according to their origins is as follows: 


\begin{tabular}{|c|c|c|}
\hline \multicolumn{3}{|c|}{$\begin{array}{l}\text { Total number of websites (corpus JSI Web Corpus 2014- } \\
\text { 2016): } 252\end{array}$} \\
\hline \multirow{3}{*}{$\begin{array}{l}\text { French } \\
\text { websites: } \\
201\end{array}$} & Specifically French & 188 \\
\hline & \multirow{2}{*}{$\begin{array}{l}\text { French-speaking websites } \\
\text { (adaptations from Anglo- } \\
\text { American and francophone } \\
\text { websites) }\end{array}$} & 13 \\
\hline & & $\begin{array}{l}\text { Including } 6 \text { explicitly } \\
\text { mentioning they are } \\
\text { francophone }\end{array}$ \\
\hline \multirow{4}{*}{$\begin{array}{l}\text { Foreign } \\
\text { French- } \\
\text { speaking } \\
\text { websites: } \\
51\end{array}$} & Europe & $\begin{array}{l}\text { Belgium: } 15 \\
\text { Switzerland: } 7 \\
\text { Luxembourg: } 2 \\
\end{array}$ \\
\hline & North America & Canada: 11 \\
\hline & Africa & $\begin{array}{l}\text { Algeria, } \quad \begin{array}{l}\text { Morocco, } \\
\text { Tunisia, Mauritania, } \\
\text { Mauritius, others: } 15\end{array} \\
\end{array}$ \\
\hline & Middle East & Lebanon: 1 \\
\hline
\end{tabular}

Table 1. Distribution of websites according to their origins

Table 1 represents the distribution of websites according to their origins. Out of 252 websites, 201 are French so nearly 4 out of 5, and 51 are from foreign Frenchspeaking websites so nearly 1 out of 5 . I deemed it important to keep French-speaking websites to see whether running and its declensions are used with the same forms and meanings in other parts of the world - which seems to be actually the case. Yet, what matters most is the specifically French data since they can help explain the incorporation of running into the French language.

Tables 2 through 5 shelve the data according to the nature of the websites. Classifying the websites according to their nature enabled me to identify the frequency of running and its declensions, in order to see whether running is confined within the specialized language and world of sports. The nature of the websites has been defined according to their main field of competence. Six areas have been distinguished through the processing of the websites: general information press; regional press; computing and technology; lifestyle, culture and entertainment; sports; economy and business. General information press websites are concerned with current events and deal with a range of various topics (national and international general news, politics, economy, sports, etc.). They include typical French press and radio websites such as Le Monde, Le Figaro, Libération, RTL, France Info, etc. Foreign French-speaking general information press websites include 24.ch for Switzerland, 7sur7.be for Belgium, cridem.org for Mauritania, or huffingtonpost.ca for Canada. Regional press websites are usually the mirrors of the written regional press, but not exclusively. Each French region has its own newspapers and/or websites, such as Le Bien Public for Burgundy, Le Courrier de 
l'Ouest for the west of France, La Montagne for the Auvergne, Clicanoo for La Réunion, etc. It is the same for foreign French-speaking countries (e.g. acadie.ca for Canada, anderlecht.be for Belgium, lagruyere.ch for Switzerland). Computing and technology websites deal with computing, science and new technologies. In my corpus, these websites are essentially concerned with connected objects and devices in the world of sports (e.g. 01net, Clubic, Numerama). Lifestyle, culture and entertainment websites are about fashion, communication, people, shows, culture, ways of life and life hacks for a better life, health, diet, etc. They include: websites dedicated to fashion, beauty and well-being (e.g. Canoe in Canada); websites dedicated to women (e.g. Elle, Femme Actuelle, Terrafemina, Madmoizelle); websites dedicated to men (e.g. Chaussures-Homme); websites dedicated to fashion aficionados (e.g. Viacomit); websites dedicated to celebrities (e.g. Pure People, Staragora); websites dedicated to TV shows (e.g. Telerama). Sports websites exclusively deal with sports topics (e.g. Football365, Jiwok, L'Equipe, Velo101, We Love Tennis). Finally, economy and business websites are about finance, economy, and business matters (e.g. Boursier, Capital, Kiss Kiss Bank Bank, Zone Bourse). The distribution of the websites according to their nature is as follows (in descending order):

\begin{tabular}{|l|c|c|}
\hline \multicolumn{1}{|c|}{ ALL WEBSITES } & NUMBER & PERCENTAGE \\
\hline Total number & 252 & $100 \%$ \\
\hline General press information & 86 & $34.13 \%$ \\
\hline Regional information & 51 & $20.24 \%$ \\
\hline Computing and technology & 47 & $18.65 \%$ \\
\hline $\begin{array}{l}\text { Lifestyle, culture and } \\
\text { entertainment }\end{array}$ & 38 & $15.08 \%$ \\
\hline Sports & 18 & $7.14 \%$ \\
\hline Economy and business & 12 & $4.76 \%$ \\
\hline
\end{tabular}

Table 2. Distribution of all analyzed websites according to their nature

\begin{tabular}{|l|c|c|}
\hline \multicolumn{1}{|c|}{ FRENCH WEBSITES } & NUMBER & PERCENTAGE \\
\hline Total number & 201 & $100 \%$ \\
\hline General press information & 48 & $23.88 \%$ \\
\hline Regional information & 47 & $23.38 \%$ \\
\hline Computing and technology & 46 & $22.89 \%$ \\
\hline $\begin{array}{l}\text { Lifestyle, culture and } \\
\text { entertainment }\end{array}$ & 35 & $17.41 \%$ \\
\hline Sports & 17 & $8.46 \%$ \\
\hline
\end{tabular}




\begin{tabular}{|c|c|c|}
\hline FRENCH WEBSITES & NUMBER & PERCENTAGE \\
\hline Economy and business & 8 & $3.98 \%$ \\
\hline
\end{tabular}

Table 3. Distribution of French websites according to their nature

\begin{tabular}{|l|c|c|}
\hline \multicolumn{1}{|c|}{ FOREIGN WEBSITES } & NUMBER & PERCENTAGE \\
\hline Total number & 51 & $100 \%$ \\
\hline General press information & 38 & $74.52 \%$ \\
\hline Regional information & 4 & $7.84 \%$ \\
\hline Computing and technology & 1 & $1.96 \%$ \\
\hline $\begin{array}{l}\text { Lifestyle, culture and } \\
\text { entertainment }\end{array}$ & 3 & $5.88 \%$ \\
\hline Sports & 1 & $1.96 \%$ \\
\hline Economy and business & 4 & $7.84 \%$ \\
\hline
\end{tabular}

Table 4. Distribution of foreign websites according to their nature

\begin{tabular}{|l|c|c|c|}
\hline \multicolumn{1}{|c|}{ WEBSITES } & FRENCH & FOREIGN & TOTAL \\
\hline Total percentage & $79.76 \%$ & $20.24 \%$ & $100 \%$ \\
\hline General press information & $19.05 \%$ & $15.08 \%$ & $34.13 \%$ \\
\hline Regional information & $18.65 \%$ & $1.59 \%$ & $20.24 \%$ \\
\hline Computing and technology & $18.25 \%$ & $0.4 \%$ & $18.65 \%$ \\
\hline Lifestyle, culture and entertainment & $13.89 \%$ & $1.19 \%$ & $15.08 \%$ \\
\hline Sports & $6.75 \%$ & $0.4 \%$ & $7.14 \%$ \\
\hline Economy and business & $3.17 \%$ & $1.59 \%$ & $4.76 \%$ \\
\hline
\end{tabular}

Table 5. Overview of the percentages of all the websites according to their nature

It is noticed that whether the websites are specifically French or not, the sports category does not come first. It may suggest that running is not a specifically codified sport like football, tennis or rugby: it is more accessible as anyone can just put on running shoes and go out for a run. Running and its declensions are mostly encountered in the general information press websites, followed by the regional information press websites. What has been remarked in nearly all occurrences is that running and its variants are encountered in the sports pages - especially for the regional press relating local sports events, given the context I could grasp in the extracts - but not only: running is also frequent in pages devoted to society and lifestyle. Surprisingly, the category "computing and technology" comes third: it is presumably because of the 
development of new technologies around sports, particularly connected objects such as watches, wristbands, applications on smartphones... Interestingly enough, the category "lifestyle, culture and entertainment" comes fourth, probably meaning that running has become synonymous with both an enjoyable activity and a healthy way of life in keeping with the contemporary codes of the consumption society - consuming a thing or an activity in order to line up one's status, identity, style and appearance with given standards, to look for pleasure, and to achieve performance (Kara, 2009). The category "economy and business" eventually comes last: running has been generating a new form of economy and business around sports equipment, technology and lifestyle.

\subsubsection{Results according to occurrences}

The next classifications concern the 2825 occurrences containing the letters "runn" - following the methodology stated above, dealing with the field of running as a sports activity. I also manually examined the 2825 saved in the Excel file, thanks to a range of colors allowing me to distinguish between running as referring to the sports activity, the name of a club or of a connected device, a pair of shoes, etc. The results are presented in the two tables below. It is worth noting that sometimes it was difficult to attribute a clear referent to some occurrences as they would hover between at least two spheres - for example, some instances would refer both to running clubs and their websites. This is the reason why the results shown in Table 7 may slightly differ from the inventory presented in Table 6. Capitalization being randomly distributed in the database - so not necessarily corresponding to a proper noun and vice versa -, I have decided to record all the lemmas with lowercase letters.

Table 6 lists all the found occurrences ${ }^{11}$ according to types (representing distinct semantic referents) and tokens (instances of a given type) in alphabetical order. Table 7 recapitulates the different referents running is associated with in descending order.

\begin{tabular}{|c|c|c|c|}
\hline TYPES & TOKENS & REFERENT & $\begin{array}{c}\text { PART OF } \\
\text { SPEECH }\end{array}$ \\
\hline runner ${ }^{12}$ & 2 & Action of running & Verb \\
\hline runner ${ }^{13}$ & 83 & $\begin{array}{c}\text { Part of the name of a } \\
\text { connected app, site, or object }\end{array}$ & $\begin{array}{c}\text { Noun and proper } \\
\text { noun }\end{array}$ \\
\hline runner ${ }^{14}$ & 12 & $\begin{array}{l}\text { Part of names of clubs, } \\
\text { teams, magazines, contests, } \\
\text { or events }\end{array}$ & Proper noun \\
\hline runner & 3 & $\begin{array}{l}\text { A stroller designed for } \\
\text { mothers practising running }\end{array}$ & $\begin{array}{c}\text { Noun and proper } \\
\text { noun }\end{array}$ \\
\hline runner ${ }^{15}$ & 8 & Running shoes & $\begin{array}{c}\text { Noun and proper } \\
\text { noun }\end{array}$ \\
\hline runner/runneur & $274 / 11$ & A man who practises running & Noun \\
\hline runner-traileur & 1 & A man who practises both & Compound noun \\
\hline
\end{tabular}




\begin{tabular}{|c|c|c|c|}
\hline TYPES & TOKENS & REFERENT & $\begin{array}{l}\text { PART OF } \\
\text { SPEECH }\end{array}$ \\
\hline & & running and trail & \\
\hline runner's high & 1 & $\begin{array}{l}\text { A state of euphoria felt while } \\
\text { running }\end{array}$ & Compound noun \\
\hline runneuse $^{16}$ & 32 & $\begin{array}{l}\text { A woman who practises } \\
\text { running }\end{array}$ & Noun \\
\hline running ${ }^{17}$ & 1281 & The activity of running & Noun \\
\hline running $^{18}$ & 366 & $\begin{array}{l}\text { Part of names of clubs, } \\
\text { teams, contests, venues, or } \\
\text { events }\end{array}$ & Proper noun \\
\hline running ${ }^{19}$ & 313 & Running shoes & Noun \\
\hline Running ${ }^{20}$ & 313 & $\begin{array}{l}\text { Part of the name of a } \\
\text { connected app, site, or object }\end{array}$ & Noun \\
\hline running ${ }^{21}$ & 65 & $\begin{array}{l}\text { Accessories and shops linked } \\
\text { to running }\end{array}$ & Noun \\
\hline running ${ }^{22}$ & 26 & $\begin{array}{c}\text { Part of names of challenges } \\
\text { and contests }\end{array}$ & Proper noun \\
\hline running-business & 1 & Business around running & Compound noun \\
\hline runningcafe & 1 & Website dedicated to running & Compound noun \\
\hline running-club ${ }^{23}$ & 21 & $\begin{array}{c}\text { Names of running clubs in } \\
\text { France }\end{array}$ & Compound noun \\
\hline running-conseil & 1 & Name of a running shop & Compound noun \\
\hline runningfood & 2 & Name of a book on running & Proper noun \\
\hline runninglicious & 1 & Blog on running & Blend \\
\hline running-poussette & 2 & $\begin{array}{l}\text { A stroller made for running } \\
\text { and running with a stroller }\end{array}$ & Compound noun \\
\hline running-team & 1 & A team of runners & Compound noun \\
\hline runnistique & 2 & Typical of running & Adjective \\
\hline runnosphère & 2 & $\begin{array}{l}\text { A web community around } \\
\text { running }\end{array}$ & Blend \\
\hline
\end{tabular}

Table 6. List of the 2825 occurrences (in alphabetical order) 


\begin{tabular}{|l|c|c|}
\hline \multicolumn{1}{|c|}{ REFERENT } & $\begin{array}{c}\text { NUMBER OF } \\
\text { ITEMS }\end{array}$ & PERCENTAGE \\
\hline Total & 2825 & $100 \%$ \\
\hline Sports activity & 1282 & $45.38 \%$ \\
\hline $\begin{array}{l}\text { Places, clubs, events, } \\
\text { contests, books }\end{array}$ & 433 & $15.33 \%$ \\
\hline Computing and technology & 401 & $14.19 \%$ \\
\hline Sports shoes & 321 & $11.36 \%$ \\
\hline $\begin{array}{l}\text { People practising running } \\
\text { (both men and women) }\end{array}$ & 318 & $11.26 \%$ \\
\hline $\begin{array}{l}\text { Accessories, clothes, } \\
\text { fashion, trade, shops }\end{array}$ & 68 & $2.41 \%$ \\
\hline Others & 2 & $0.07 \%$ \\
\hline
\end{tabular}

Table 7. Distribution of the 2825 occurrences of running and declensions according to their fields of reference (in descending order)

Obviously, when looking at the results, running is mainly a sports activity (45.38\%) with its places and events (15.33\%), its sophisticated equipment (14.19\% for technology, $11.36 \%$ for shoes and $2.41 \%$ for other practical accessories), and its practitioners (11.26\%). Tables 6 and 7 confirm the predominance of technology and specific equipment surrounding running in French. This potentially means that running conveys a whole world with a well-oiled machine. The word running is overrepresented with a total of 2398 tokens (blends mixing English and French hybrids, compounds and proper names included). Running also has various declensions including morphological derivations: nouns runner/runneur (11 tokens for runneur which adopts the French nominal suffix “-eur” for agent nouns) and its corresponding feminine form runneuse (32 tokens) following the French inflectional gender forms; a verb belonging to the first group runner (2 tokens: one in the infinitive form, and one conjugated "ils runnent"); and even an adjective formed with the adjectival suffix "-istique” runnistique. Plural forms are also included in the list and amount to 333 (all tokens taken together). More interestingly, running and runner can refer to various elements, hence constituting different types although the forms are similar. Running is thus a flexible word in terms both of morphology and semantics.

The next subsection presents a sample of French online publications collected from 2004 to 2018 - to complement the empirical data with more context. 
3.2. Presentation of the data collected from the sample of French online publications from 2004 to 2018

I explored a variety of French online publications (articles, briefs, podcasts, forums) dedicated to running. The objective is to demonstrate the importance running has acquired in all sectors, thanks to a qualitative analysis of the contents and points of views provided. Furthermore, reviewing entire publications allows for a better contextualization of running.

Fifty publications have been examined for this purpose. They were selected according to the following method. On Google France, I successively typed the keywords "running phénomène", "running mode", "running évolution", and "running business". Then, I selected the results displayed (at that time ${ }^{24}$ ) on the first and second pages. I proceeded to the classification of the 50 publications according to their dates, sources, and topics. The results are explained below.

The dates of the publications range from 2004 to 2018. Such a choice is motivated by the fact running has in fact been used in France for about twenty years, as one of the websites mentioning its integration remarks. ${ }^{25}$ Overall, 1 publication is from 2004; 1 from 2006; 1 from 2011; 2 from 2013; 5 from 2014; 13 from 2015; 11 from 2016; 8 from 2017; 4 from 2018; and 4 which are not dated.

The sports sites come first with 22 publications (including 2 forums and 3 blogs), followed by lifestyle, culture and entertainment (12, including the Académie Française and a blog), the general information press (11, including 2 podcasts), economy and business (3), and the regional press (2).

The main topics which stand out are: running as a phenomenon; running as a trend; running as an evolution of the practice of running; running as a business; and running as a question of language. The details are developed below.

Twelve publications dating from 2013 to 2017 deal with running as both a sport and a social phenomenon. 6 are from the general information press; 2 from the regional press; 2 from the lifestyle, culture and entertainment press; and 2 from the sports sites. The ideas exposed in these publications overlap: they all agree that running in France has become a social phenomenon. Running deals with competition and performance, and differs from the other Anglicisms jogging and footing more linked to leisure in French - from what is perceived in the publications. Running takes on a community dimension especially thanks to social networks - which is in accordance with new technologies always reinventing themselves to enhance the sports practice. Additionally, running generates a growing popularity with millions of practitioners (men and women alike) each year; and subsequent events and competitions combining fun, fellowship, and sports. Moreover, running has reached such a dimension as debates and symposiums are organized around it, especially by the Fédération Française d'Athlétisme (French Federation of Track and Field).

Fifteen publications dating from 2015 to 2018 deal with running as a trend and even as a lifestyle. 10 are from the sports sites; 4 from the lifestyle, culture and entertainment press; and 1 from the general information press. These publications all state that running in France has become a fashionable way of practising running. They 
insist on the trendiness of the activity linked to its accessibility and easiness, its community dimension, the cool healthy look it gives you - flashy clothes and shoes, stylish accessories, ostentatious smart objects, etc. A few publications having a more or less critical standpoint think running is just a fad which will be replaced by another. One site joyfully plays on words with the expression "welcome les runnistas", probably modelled after "fashionistas".

Nine publications dating from 2014 to 2017 present the idea of sports and life evolution around running. 3 are from the general information press; 3 from the lifestyle, culture and entertainment press; and 3 from the sports sites. These publications emphasize the evolution of the activity of running, sometimes going back to the times when it was confined within the limits of a stadium and reserved to men. Also highlighted is the evolution from jogging to running: the former makes us think of a lonely relaxed way of running, while the latter is meant to boost performance, to share it within a community and to improve it thanks to technology and fashion.

Six publications dating from 2013 to 2018 raise the issue of economy and business around running. 3 are from the business and economy press; 1 from the sports sites; 1 from the lifestyle, culture and entertainment press; and 1 from the general information press. These publications say that running has become a thriving business, especially around sport equipment, technology and fashion - and it is frequent all three sectors join up to develop a lucrative market around running, particularly thanks to the help of startups. The sectors play on the democratization and massification of the practice of running. The products which are developed and commercialized are often expensive, yet comfortable. They contribute to making the practice of running even more complex and sophisticated.

Eight publications dating from 2004 to 2018 tackle the question of language and terminology around running. 6 are from the sports sites; and 2 from lifestyle, culture and entertainment websites. While some publications acknowledge the competitiveness, regularity and intensity conveyed by the word running - hence leading to its integration into the dictionary -, others stress the confusion it may create especially as it coexists with footing and jogging. One publication highlights the fact running is a noble sport contrary to footing and jogging. Conversely, the Académie Française is ironical about the fact that running appears to be totally different from the traditional French course à pied - before authoritatively indicating that one cannot say "Je vais faire du running" and "Des chaussures de running". Finally, some websites propose a "dictionary" around running, which looks more like a sports glossary around running.

The data from a journalistic corpus and the random selection tend to prove running has become a social phenomenon and a successful lifestyle, representing a new culture of performance with its own codes and vocabulary. The next section endeavors to interpret the collected data to demonstrate how the Anglicism running in French has become the privileged lexeme to talk about this phenomenon. 


\section{Interpretation and discussion of the results}

In this section, different criteria will be tackled: the significance of running in terms of figures; the Englishness conveyed by running; the language around running; and the semiotics around running.

\subsection{Significance of running in terms of figures}

Running is said to have been used for about 20 years before entering the French dictionary. It was maybe initially quite unnoticed, as it was in competition with the French course à pied, and the false Anglicisms jogging and footing: such a long lifespan maybe doubled with an obscure beginning - probably confined within a few communities of sports amateurs ${ }^{26}$ - does not necessarily speak in favor of running as a buzzword. However, what the database illustrates in this paper is that running suddenly grew in popularity around the end of the 2000s, and especially in the 2010s. One reference states that running in 2018 was searched on the net four times more than its French counterpart course à pied. ${ }^{27}$ The popularity inherent in a buzzword can thus be identified in running. First, because of the figures: no less than 2825 occurrences have been censused within the two-year period 2014-2016. On an indicative basis, a quick search on the French press archive portal Europresse - but with no cleaning up of the data, so probably mixed with occurrences found in domains other than sports - shows that between early January 2017 and early April 2019, running was mentioned 22772 times, and 339 in the plural; runner 12,291 times, and 3873 in the plural; runneur 17 times, and 136 in the plural; runneuse 88 times, and 77 in the plural. Even if these data may be a little erroneous, they still show that running and its declensions were widely used in the French online press in another two-year period. This may well indicate running is a buzzword through such wide use in such little time. Given these figures, running therefore seems to hold its promise of popularity.

\subsection{Englishness conveyed by running}

Englishness within running is also representative. Surprisingly enough, the collected data in the 2014-2016 corpus only contain 329 occurrences of the French course. A more thorough research reveals there are only 90 occurrences of the expression course à pied. Similarly, there are 106 occurrences of coureur(s) (99) and coureuse(s) (7) compared to the 318 occurrences of runner(s) (275), runneur(s) (11), and runneuse(s) (32). The figures are undoubtedly in favor of the words of English origin. The analysis of the online publications indicates running is different in meaning and practice from course à pied. Two questions arise: firstly, how can a word of English origin induce innovation and subsequent sensation inherently linked to the buzz in the recipient language? Secondly, does this specifically English origin automatically generate a new concept in the recipient language? 
The answer to these closely related questions may lie in the prestige naturally induced by the Englishness of the word. The appearance of the word already catches the eye. First, because it looks and sounds foreign. Moreover, some tokens are accompanied with flagging cues testifying to the foreignness of the word. For instance, 150 occurrences of running and its declensions in the 2014-2016 corpus are found between inverted commas. Only 6 occurrences of running are followed by a French translation (course à pied) given in brackets. Adding inverted commas or translations to a loanword contributes to marking its foreign status, as Saugera recalls; yet she also mentions that these flagging devices and others are not infallible: "Even when flagging is used to convey conscious use of an Anglicism, there is no clear proof that it indicates a lack of integration into the recipient language” (Saugera, 2017: 31). In the case of running, the tokens explicitly accompanied with flagging cues are not very numerous a total of 156 out of 2,825. Does this prove the uselessness of indicating the English origin of running? Thus, does that prove the integration of running into standard French? The 2014-2016 corpus data extracted from Sketch Engine are unclear in terms of flagging cues: only the inverted commas and the translations in brackets are visible. With the transfer of the data to Excel, it is impossible to know whether some tokens were originally written in italics.

Another aspect of the foreignness of running and its declensions is their assimilation to the normal French morphological rules of gender and plural.

For gender, it is noted that running (the activity) is systematically provided with a masculine gender article ("le running"). This is somewhat typical of names of sports of Anglo-American origin like "le football”, "le rugby”, "le golf", "le tennis", "le rafting", "le twirling", etc. When running refers to the shoes, it follows the French feminine gender rule of chaussures: gender information is provided either through the feminine article "la" in the singular, or through the attributive adjective bearing the feminine ending (e.g. "la running", "la running shoe", "les running imprimées", "les running connectées”). By comparison, there are 11 occurrences of running shoe(s) from Canadian websites indicating the masculine gender ("le running shoe").

For the plural form, all tokens included, there are 333 explicit plural forms: 241 runners, 64 for runnings, 18 for runneuses, 9 for runneurs, and 1 for runnings-bottes. This means running and its declensions are morphologically flexible as they naturally adopt the standard French inflectional rule of the plural principally represented by the ending in $-s$. However, in the French websites, it is surprising to find a few utterances in the plural but with no $-s$ for running and runner: 9 occurrences for running shoes (e.g. "chausser les running", "on tâtonne au niveau de l'équipement, à commencer par les running", "les running Ignite correspondent aux besoins de beaucoup de sportives", "les running imprimées en 3D”, "les running connectées”, "le temps des running version citadine”); and 2 occurrences for practitioners ("les lipides sont beaucoup moins performantes que les glucides pour les runner en recherche de performance”, "alarme pour les runner ou comment se protéger"). The lack of plural form for these few tokens may reflect the foreignness of the word, as usually foreign words remain invariable in French when not integrated. It may be concluded from this that there is still some 
grammatical instability around running and runner in French, since they come from another language system. Nevertheless, these occurrences are sparse and cannot really be representative of the question of the integration of running into French.

Overall, running has followed the Saussurian principle: in order to function and exist, a word must adapt to the phonological system of the language - running is pronounced with the French phonemes / $\mathrm{s} /$ and /ng/ contrary to the English phonemes $/ \mathrm{r} /$ and $/ \mathrm{y} / \mathrm{-}$, and to assimilate the morphological rules - here gender and plural.

\subsection{Language around running}

As mentioned in Section 2, the English language has undeniably gained importance since the past century. English is especially synonymous with progress and globalization, because of its predominance in technology, business, and communication. Greavu \& Zdrenghea (2010: 132) note:

Another important factor which has been shown to influence the integration process is an attitudinal one, and it refers to whether the recipient language speakers want or do not want to sound like donor language speakers. Such attitudes can be promoted by certain values attached to foreign sounding or looking words, for example social prestige or fashion. This aspect can be of great importance in today's linguistic global environment, where English has become the international language of business and communication and is being increasingly perceived as modern and fashionable.

Clearly, the Englishness contained in running seems to promote a new kind of running, more modern through technology, and more fashionable through equipment and the healthy way of life it offers, as perceived in the database. The above-mentioned attitudinal factor may here correspond to the use of the word not only to sound English, but to adopt a way of speaking and living in accordance with the social prestige and fashion the word implies. As regards with Rodríguez González's study (1996), the Anglicism running may be used in the "interpersonal" function in French: the underlying feeling and connotation contained in running would be affectation (prestige) and performance (the best way to run, to be healthy and to be modern). A community of runners/runneurs and runneuses builds around running - in fact, a community of adepte(s) (57 occurrences) and communauté(s) (26) worshipping running ("un véritable culte au running”, "culte de la performance”, “culte du corps”). Furthermore, some of the publications stress the fact running possesses its own dictionary ("le dictionnaire du running"), thus its own language which can be deciphered by the happy few who practise it. This is called "ingroupness" - i.e., belonging to a specific group with its own codes and criteria of admission and recognition. Such specific language could be considered jargon for the non-initiated. Or it could be a kind of slang, used to reinforce cohesiveness (another sports value) within the community of runners, or to illustrate the fashion of the moment - the goal being reaching performance.

Performance around running can be seen in the co-occurrences usually found in the utterances containing running, especially implied in those referring to the world of 
sports - since, intrinsically, practising a sport means ultimately reaching performance. For example, there are 60 co-occurrences of running with jogging; 24 with footing; 182 with trail; 56 with fitness; 52 with coach; 55 with tennis (both sports and shoes); 15 with training; 41 with challenge; etc. As it happens, these sports co-occurrences are Anglicisms. Moreover, there are a few co-occurrences which are lexicalized since they refer to a particular type or object of running: 43 with free (free running, a kind of obstacle race in which one can perform gymnastic moves); 36 with trail (trail running, which consists in a long race through nature); 17 with tower (tower running, which consists in climbing stairs and buildings as quickly as possible); and 14 with map (running map, a map tracing the course). Other Anglicisms can be found around running: apps (2), blog (15), boom (8), business (3), buzz (8), fun (20), glamour (3), healthy (1), life (14), lifestyle (4), marketing (7), playlist (25), shopping (1), startup/start-up (9), top (61), week-end (21)... It is as if an Anglicism attracted others. Saugera (2017: 97-98) remarks:

English fuels various kinds of jargon in French. In the daily press, business jargon and fashion jargon illustrate this neological function of English, which routinely manifests a serial effect in which the use of one English word triggers the use of others.

Furthermore, the Anglicisms around running either belong to the fields of sports (trail, football, tennis), entertainment (fun, shopping, week-end, buzz, glamour, top), lifestyle (life, lifestyle, healthy), technology (apps, blog, playlist), evolution (boom), or business (business, marketing, startup). This is logically linked to the nature of the websites examined for this study. But this also demonstrates something interesting. The semantic fields of those co-occurrences suggest running is positively connoted around the notion of performance: performance in terms of sports (running is a sports in itself), entertainment (it is a smart hobby), lifestyle (it contributes to a better health), technology (it is modern), evolution (boom means both "prosper" and "burst", there is the "running boom" like the baby boom), and business (it generates a thriving industry). To a certain extent, running is thus used in the "interpersonal" function described by Rodríguez González. Running may also have a positive semantic prosody - according to Louw's principle (1993) - because running is often found with positive cooccurrences conveying the idea of performance, whatever the semantic fields.

Running is also accompanied by telling French co-occurrences. The privileged semantic fields are: craze - engouement (15), événement/évènement (64), folie (10), passion (32); history and sociology - histoire (15), phénomène (30), philosophie (1), révolution (13); universe - monde (66), salon (55), temple (1), univers (31); language bible (4), dico (11), dictionnaire (3), magazine (19); performance and innovation performance (36), innovation (16); and economy - boutique (26), entreprise (20), magasin (26), marché (36). The utterances in which these examples of co-occurrences appear also show that running is preferably found as a nominal complement ("salon du running", "la philosophie du running", "l’univers du running", "le monde du running”, "la bible du running, "le dico du running", "le marché du running", "la folie du running”, “l’engouement pour le running”, "l’événement running de l’année”, etc.). 
The Anglicism running can therefore be used in many opened constructions, giving it the possibility to be found in an infinity of utterances in different semantic fields. It can thus be found in any kind of paradigmatic relation. This implies that running can broaden its scope of application instead of being restricted in fixed prepositional groups - the database does not contain any occurrence such as "running de fond", "running à pied", "running d'endurance", which are on the contrary typical declensions of the French course in order for this word to be clearly related to a type of sports.

In this perspective, the Anglicism running may be associated with the "textual" function delineated by Rodríguez González (1996). Indeed, since it can occur in different contexts and always be identified as the activity or the shoes, running displays the criteria of simplification, clarity and precision that are typical of the "textual" function. Let us consider the following examples. It is quicker - so simpler - to say "les runnings connectées" instead of "les chaussures de course connectées": the Anglicism is reduced to a two-syllable word. Thanks to the plural and feminine forms of the article and adjective, we can also understand we are talking about the shoes. It is more precise to say "Je vais faire un running" instead of "Je vais faire une course": what "course" is it? A car race? A speed race with a friend? Or shopping? Even when trying to give a precision in French ("Je vais faire une course à pied", "Je vais faire une course de vitesse"), the confusion remains - with going shopping on foot for the former, and with the means of locomotion for the latter (on foot, by car...). With running, one knows straight away what kind of sports is referred to. The same may be observed when comparing "le Sancerre Running Club" and "le club de course de Sancerre": what type of sports "course" is? And it is the same when comparing "le running est le sport le plus pratiqué" with "la course est le sport le plus pratiqué": in French, "course" has to be specified ("la course à pied est le sport le plus pratiqué") in order not to confuse it with any kind of "course" (course automobile, course de vitesse, course de fond, etc.). In French, all these utterances may be ambiguous because of the large polysemy of "course". Whereas course needs to be complemented or given a context to be used and understood (course à pied, chaussures de course, course automobile, course meaning "shopping"), the one-word Anglicism running avoids polysemous clashes and offers immediate precision - hence the possibility to be unequivocal and direct. Such precision is paired with the broadening capacity of running: because it is precise, running can be found in any semantic context and always identified as the sports activity or the shoes it refers to.

The capacity of running to extend both its lexical and semantic applications to domains other than sports is typical of Anglicisms (Saugera, 2017: 46), or polysemous borrowings which open onto new perspectives compared to their original meaning in the donor language (Chesley, 2010). This can be regarded as linguistic creativity: indeed, broadening and therefore recreating meaning in an already existing basis contribute to creating both a new lexeme and concept. However, one may logically talk of productivity since the uses of running and its declensions in French seem to be part of the productive processes which can be used ad hoc, i.e. for the specific needs 
required by the practice of running in the $21^{\text {st }}$ century - this practice being different from the one that existed some decades ago, as the dataset indicates.

\subsection{Semiotics around running}

The significance and popularity of running eventually go beyond the dimension of the word. The sample of 50 French online publications together with the contexts provided by the 2014-2016 corpus highlight the fact running is associated with performance, and has thus become popular and trendy among both sports specialists and amateurs. This is quite in keeping with the popularity surrounding a buzzword. Running somehow marks 'updatedness' through specific accessories and codes. For instance, famous sports and technology brands fight on the running market to keep offering the best and most innovative products ever - e.g. RunningHeroes, a web platform designed to connect runners together and to reward their effort; Nike+ and Runtastic, applications on your smartphone supposed to upgrade your running performance; the Garmin Forerunner 620, defined as a high-tech connected watch, which is in competition with the TomTom Cardio Runner; the Enko Running Shoes, meant to revolutionize the way you run thanks to incredible comfort and resistant material combined with an innovative design, in competition with Nike and Adidas too; and so on and so forth. ${ }^{28}$ Taking a close look at the English names of these brands and products also contribute to emphasizing the idea of performance around running: nouns (e.g. heroes in Running Heroes) and affixes (e.g. -tastic in Runtastic, copied from the adjective "fantastic"; fore- in Garmin Forerunner, implying this watch is ahead of others) are all positively connoted. The business around running is meant to constantly arouse excitement by proposing accessories associated with innovation and performance - which are in fact characteristic of the buzz. The 2014-2016 corpus figures tend to confirm this: added all together, the tokens related to shoes, technology and other accessories account for $27.96 \%$, so nearly a third of all occurrences.

Additionally, the contexts of the corpus mention new kinds of running events and contests in France (also bearing English names) involving specific codes of performance: the Mud Day, a run in the mud, and the Color Run, a run in which runners are thrown different color sprays. In both cases, the contestants go through difficulties and must surpass to finish the race all stained with mud or colors - which is also supposed to add fun to the competition. And even if there is no mud or color spray, the holy grail for a runner is to take part in local, national, and international contests such as marathons and charity runs, wearing their team's colors - e.g. "les Beauty Runneuses" for the cosmetic brand Sephora, "les Color Runners" for a charity association, "les Runneurs des Vignes" in Poitiers, etc. Accessories, colors, evocative team names... All these seem to be in line with the adding effect produced by a buzzword; the particularity here with running is that the word is accompanied by visible signs. Hence an important semiotic dimension around running. Running makes the buzz because it conveys a dimension of visibility and competition reinforcing the impression of adding effect. Visibility means that, to be performant, you need to be visible by being 
endowed with specific accessories, being part of a team or a community, and taking part in specific contests. Competition means that to be performant in running you must always strive to push beyond your limits - and this is somehow represented in the running market which keeps pitting products against one another, and in the running communities which keep challenging one another. Besides, the semiotic dimension of running does not only create the buzz: it also goes along with the extension of running from a mere activity to a full-fledged sport with its own rules and codes.

Regarding the linguistic dimension around performance and the semiotic dimension revolving around competition and visibility, running thus conveys the cult of appearance and consumption typical of today's consumer society (Kara, 2009: 158), hovering between useful values - sports, health - and vain values - fun, style, challenge - , to eventually achieve the ultimate performance of being the best.

\section{Conclusion}

The present study has focused on the newly integrated Anglicism running and its declensions in contemporary French. It has shown the importance running has gained over time. Such importance is not only linguistic, but also closely related to the evolution of the practice of running in contemporary France. Was running a buzzword in the first place? Yes, as a buzzword is meant to trigger popularity and subsequent craze for it and for what it represents in given circumstances and period, and among given people. It is certainly the case with running: this hypothesis is thus confirmed, because running exemplifies sports performance through its Englishness associated with modernity, in the field of sports and among communities of runners.

But running has jumped from the microcosm of a buzzword to the universe of a lexeme designating a new concept of running. This new concept of running is fierce, flashy, and fashionable, building around new technology and new sociocultural codes. It has developed its own style and aesthetics. Sports performance is supposed to be better with running than with course à pied. Visibility and competition are key in understanding the difference between the newly integrated Anglicism running and the traditional French word course. To a certain extent, one may talk of publicity for running. Publicity is the attention someone or something gets from the media, and the business of making sure that people know about a new product or concept. As Kara (2009: 166) notes, "Une consommation de masse nécessite la publicité pour assurer sa permanence". ${ }^{29}$ The goal of running as a sports activity and as a business is to attract attention, to be noticed and noticeable, and to be made widely available - and consumed.

Considering that, running may well still be a buzzword despite its recent integration into the dictionary. This buzzword has achieved the performance of extending the scope of running by following the new criteria of the contemporary society. At the same time, its scope of application has gained in precision. Running appears to have more semantic possibilities than its French counterpart. The other hypothesis of this study is therefore verified, albeit with a reservation regarding the 
innovation this Anglicism is supposed to bring to the French language. Indeed, the action and practice of running have always existed and therefore cannot be invented; they can only be reinvented with new products and new words. It is a question of perspective: how you make something already existing appear under a new light. The innovation brought by these new words and products gives the illusion that because the concept is new, it is better - and thus more performant. One occurrence in the database even distinguishes between running and sports in general: "le running et le sport", as if running were something more than sports! As long as there is attention, attraction and consequent consumption for this seemingly new sports concept, the Anglicism running and what it represents will still be performant - that is to say, a popular way of doing sports and a booster feeding the field of running in various contexts (sports, technology, health...). But the newly integrated Anglicism running may just be an accessory to promote a concept and may be here only to "fulfill spur-of-the-moment functions in the French language”, as Saugera puts it for Anglicisms temporarily borrowed and doomed to disappear if they are not recorded (Saugera, 2017: 12). Running has had the good fortune to be recorded. Yet, does that mean it will be perennial?

The aim of this paper has been to examine the motivations underlying the recent integration of the Anglicism running into the French lexicon. This specific case is of course not representative of all the sports Anglicisms, nor of all the Anglicisms in contact with contemporary French. The conclusions drawn from the investigations are built upon snapshots of written press language. Nonetheless, this study offers an insight into the pathway of a buzzword of English origin to a full-fledged French concept of sports. This study does not compare English and French usages of running, yet the following question remains open for future investigations: has running - and any other Anglicism - in French something different from the English original lexeme? To conclude, proposing and testing buzzwords of English origin in other domains would be promising avenues of research in order to demonstrate their potentialities in terms of semantic extension and precision, and their substantial roles in language contact.

\section{Notes}

* Received: May 30, 2019; Accepted: October 13, 2019

1. Definition provided by the Longman Dictionary of Contemporary English online. Accessed 14 Apr. 2019, (https://www.ldoceonline.com/dictionary/running).

2. These figures are provided by the French national newspaper Le Monde, in an online article published on 22 March 2019, https://www.lemonde.fr/lesdecodeurs/article/2019/03/22/d-ou-viennent-les-nouveaux-mots-de-la-langue-

francaise_5439961_4355770.html.

3. "linguistic borrowing takes place when a language A uses a linguistic unit or trait which previously existed in a language B - known as source language - and which A did not have; the borrowed unit or trait are described as borrowings" [my translation].

4. Sic, published on Facebook 6 May 2017.

5. I am focusing here on full lexical borrowings, being the ones which can be universally exchanged. Of course, some sport Anglicisms can undergo changes in order to adapt to the 
recipient language - such as derivation, morphological adaptation, and extension or restriction of meaning according to the local needs. There are even false Anglicisms created perhaps to perpetuate the English dominance in sports: tennisman, racingman, recordman, as Humbley notes the pattern sport + -man (in Furiassi \& Gottlieb, 2015: 51).

6. According to www.dictionary.com

7. Buzzwords can be single words, phrases, or acronyms.

8. Stylé, dès que possible, surprenant, histoire, bataille, oh mon Dieu !

9. For example, a quick search on Google France displayed about 266,000,000 results for "buzz 2010" (revealing mostly funny videos and stars' behaviors), 115,000,000 and $384,000,000$ and 1,020,000,000 respectively for "hashtag 2015" and "selfie 2015", and 16,960,000,000 for "like 2019". These figures are spectacular, but Google results are not very reliable. Yet, they can still give an overview of the scale and importance those words had on entering the dictionary. Further studies would be needed to document the topic. For instance, it would be interesting to analyze the points of view of different French newspapers on those buzzwords of English origin - such as the following article of Le Point dated August $23^{\text {rd }}$, 2017, on a decade of hashtag, the success of both the word and symbol, and its subsequent entrance into the dictionary. https://www.lepoint.fr/high-tech-internet/dix-ans-de-hashtag-2308-2017-2151718_47.php.

10. "the fact that a term moves from the specialized language to the non-specialized language - the everyday language -, a phenomenon due to its spread by different interlocutors - whose main representatives are the media” [my translation].

11. A few typo mistakes have been included: runnig (1 occurrence referring to the activity of running), and runnning ( 6 occurrences: 1 related to shoes, 2 related to the activity, 3 related to technology).

12. E.g. "je suis allée runner", "ils runnent vers le record du monde de vitesse".

13. E.g. "la TomTom Runner Cardio".

14. E.g. "les Front Runners".

15. E.g. "lancement de la 'Flight runner'", "il ne se passe pas une semaine sans qu'il ne chausse cinq fois ses runners".

16. One occurrence is found in a proper name: "le projet World Wide Runneuze".

17. Some tokens are compound nouns like "running-bike" (3 occurrences) and "runningtrail", also found in one word "runningtrail" (2 occurrences). "Trail” is quite often associated with running in the corpus.

18. E.g. "ouverture du village Running Expo", "le Trail Running Association Chevenonnaise", "le licencié du Team Running Shop", "le club Sancerre Running s'est littéralement lancé dans la course".

19. E.g. "mes chaussures de running", "une paire de running", "chausser ses runnings". An occurrence is quite difficult to classify as it stands between a sports pair of shoes for the design and a fashionable pair of shoes not meant for running: "le Kaiser a assorti ses silhouettes de runnings et même de runnings-bottes lacés jusqu'en-dessous du genou". "Runnings-bottes" is thus an example of a compound noun both mixing an Anglicism with a French word, and a sport shoe with a fashionable shoe. This is somehow characteristic of the plasticity running can have when used in French.

20. E.g. "une montre de running”, "Running Heroes”, "Runtastic et Nike + Running”.

21. E.g. "une tenue de yoga, fitness ou running", "short de running", "la mode du 'running”," "boutique de running”, “au rayon running”, "la nouvelle gamme running”, "collection running", "les accessoires de running". 
22. E.g. "le RunningManChallenge”, "les sessions Running Mad”.

23. The plays on words in clubs' names have been included such as "Runn in Sens" (3 occurrences).

24. The search on Google France was made on the $9^{\text {th }}$ and $10^{\text {th }}$ of January 2019 - i.e. at the beginning of the year 2019 which marks the integration of the Anglicism running in the official French language dictionary. I chose to stop selecting the publications at 50 , hence giving the sample a round figure which makes it easier to carry out analyses.

25. This is an article dated May $28^{\text {th }} 018$ available on the sports website L'Equipe. https://www.lequipe.fr/Coaching/Running/Actualites/Le-mot-running-entre-dans-ledictionnaire/905307.

26. The purpose of this paper actually focuses on the rapid evolution of running in the past few years and on its contemporary uses: in the absence of any quantitative evidence at the end of the 1990s, it can only be conjectured that running was not widespread.

27. This is an article dated May $28^{\text {th }} 2018$ available on the sports website Run-Motion, https://run-motion.com/running-course-a-pied-dictionnaire/.

28. Interestingly, even if some of these brands are not English or American - Enko is a French brand, and Adidas a German one -, their products bear English names.

29. "Mass consumption requires publicity to ensure its continuity" [my translation].

\section{References}

Andersen, Gisle. "Pragmatic borrowing”. Journal of Pragmatics, 67, 2014, pp. 17-33.

Béjoint, Henri. "Scientific and Technical Words in General Dictionaries". International Journal of Lexicography, 1(4), Oxford: Oxford University Press, 1988, pp. 354-368.

Bernard-Béziade, Mélanie. "L’utilisation des anglicismes dans la langue du sport en français et leur variation”. Linguistica, Revista de Estudos Linguísticos da Universidade do Porto, 3, Porto: Universidade do Porto. Faculdade de Letras : Universidade do Porto, Centro de Linguística, 2008, pp. 77-94.

Bernard-Béziade, Mélanie, and Michaël Attali. "L’évidence des anglicismes dans les discours journalistiques français. Le cas du sport”. Language Problems and Language Planning, 36(2), Amsterdam: John Benjamins Publishing Company, 2012, pp. 120-135.

Cabré, M. Teresa. La terminologi: théorie, méthode et application. Translated from Catalan, adapted and updated by Cormier, Monique C. and Humbley, John, Ottawa: Les Presses de l'Université d'Ottawa, 1998.

Chesley, Paula. "Lexical borrowings in French: Anglicisms as a separate phenomenon”. French Language Studies, 20, Cambridge: Cambridge University Press, 2010, pp. 231-251.

Colpron, Gilles, Denise Boudreau and Constance Forest, Le Colpron, dictionnaire des anglicismes. $4^{\text {th }}$ edition, Montreal: Beauchemin, 2001.

Defrance, Jacques. Sociologie du sport. $6^{\text {th }}$ edition, Paris: La Découverte, 2011.

Dubois, Jean, Mathee Giacomo and Louis Guespin. Dictionnaire de linguistique. Paris: Larousse, 2001.

Durieux, Christine. "Pseudo-synonymes en langue de spécialité". Cahiers du CIEL: Problèmes de classement des unités lexicales. Paris: Université de Paris 7, 1996-1997, pp. 89-114.

Eble, Connie. Slang and Sociability. In-Group Language among College Students. Chapel Hill and London: The University of North Carolina Press, 1996. 
Fiévet, Anne-Caroline, and Alena Podhorná-Polická. "Étude contrastive de la circulation des néologismes identitaires pour les jeunes.”Neologica, 4, Paris: Classiques Garnier, 2010, pp. 13-39.

Furiassi, Cristiano. "False Anglicisms in Italian Monolingual Dictionaries: A Case Study of some Electronic Editions”. International Journal of Lexicography, 16(2), Oxford: Oxford University Press, 2003, pp. 121-142.

Gottlieb, Henrik. "Anglicism and Translation”. In Anderman, Gunilla, and Margaret Rogers (eds.), In and Out of English: for Better, for Worse?. Clevedon, Buffalo, Toronto: Multilingual Matters, 2005, pp. 161-184.

Furiassi, Cristiano, and Henrik Gottlieb. Pseudo-English: Studies on False Anglicisms in Europe. Berlin: De Gruyter, 2015.

Greavu, Arina, and Mihai Zdrenghea. "On the Integration of Borrowings". Philologia, Studia Universitatis Babes-Bolyai, 4, Cluj-Napoca: Babes-Bolyai University, 2010, pp. 127-136.

Grosjean, François. Life with Two Languages: An Introduction to Bilingualism, Cambridge, Mass. and London: Harvard University Press, 2001.

Hallgren, F.M., and H. Weiss. “'Buzz words' at the B School.” American Speech, no. 21, Durham: Duke University Press, 1946.

Herráez Pindado, Javier. "Les emprunts aller-retour entre le français et l'anglais dans le sport". Jan. 2009, http://oa.upm.es/5785/1/INVE_MEM_2009_73172.pdf.

Humbley, John. "Emprunts, vrais et faux, dans le Petit Robert 2007". La journée des dictionnaires. Université de Cergy-Pontoise, 2007, pp. 221-238, https://halshs.archivesouvertes.fr/halshs-00275603/document.

Jeandidier, Aliénor. "Les buzzwords d'origine anglaise dans la langue française : simples anglicismes ou véritables néologismes?" Etudes de Linguisitique et d'Analyse des Discours. La néologie lexicale à travers les âges. Studies in Linguistics and Discourse Analysis. Lexical Neology through Time, HS, (1), 2018, pp. 1-34, https://revues.univlyon3.fr/elad-silda/index.php?id=303.

Josselin-Leray, Amélie, and Roda Roberts. "De la sélection des termes pour inclusion dans le dictionnaire général. Etat des lieux général et analyse critique de la terminologie informatique dans le New Oxford Dictionary of English (2000)". Colloque "Le terme scientifique et technique dans le dictionnaire général”, Lyon, 25-27 Nov. 2010, https://haluniv-tlse2.archives-ouvertes.fr/hal-00983047/document.

Kara, Ar. Gör. Bariş. "Les valeurs de la société de consommation : une analyse sémiologique des publicités de presse”. Galatasaray Üniversitesi, iletişim fakültesi, 2009, pp. 145-169.

Khoutyz, Irina. "Anglicisms as a Means of Pragmatic Marking”. Scientific Bulletin of "Politehnica”,8(1/2), Bucharest: University of Timisoara, 2009, pp. 5-11.

Louw, Bill. "Irony in the Text or Insincerity in the Writer? The Diagnostic Potential of Semantic Prosodies”. In Baker, Mona, Gill Francis, and Elena Tognini-Bonelli (eds), Text and Technology: In Honour of John Sinclair. Amsterdam: John Benjamins, 1993, pp. 157176.

Myers-Scotton, Carol. Contact linguistics: bilingual encounters and grammatical outcomes. Oxford: Oxford University Press, 2002.

Picone, Michael. Anglicisms, Neologisms and Dynamic French. Amsterdam: John Benjamins Publishing Company, 1996.

Rodríguez González, Félix. "Functions of Anglicisms in Contemporary Spanish”. Cahiers de Lexicologie, 68, Paris: Classiques Garnier, 1996, pp. 107-128. 
Rubenstein, Herbert, and John B. Goodenough. "Contextual Correlates of Synonymy". Communications of the ACM, 8(10), New York: Association for Computing Machinery, 1965, pp. 627-633.

Saugera, Valérie. Remade in France. Anglicisms in the Lexicon and Morphology of French. New York: Oxford University Press, 2017.

Taborek, Janusz. "The language of sport: Some remarks on the language of football”. In Lankiewicz, Hadrian and Emilia Wąsikiewicz-Firlej (eds.), Informed Teaching - Premises of Modern Foreign Language pedagogy. Wydwnictwo PWSZ, 2012, pp. 237-255.

Winter-Froemel, Esme. "The pragmatic necessity of borrowing. Euphemism, dysphemism, playfulness - and naming”. Taal en Tongval, 69(1), Amsterdam: Amsterdam University Press, 2017.

\section{Appendix: Consulted French online publications (from latest to earliest)}

“[Humeur] Le running, le trail ... c’est juste la mode, ça te passera”, Endomorfun, 4 September 2015, http://www.endomorfun.fr/2015/09/running-trail-mode-autocaricature/.

“ABC de la langue française: forums”, Langue Française, Informer Technologies, September 2006, http://www.languefrancaise.net/forum/viewtopic.php?id=3379.

"Bienfaits, équipement, applis: Tout savoir sur la course au pied”. Portaildelamode, https://www.portaildelamode.com/running-conseils-equipement-applis/.

“Comment le running peut vous aider au boulot”, Capital avec Management, Prisma Media, 5 June 2017, https://www.capital.fr/votre-carriere/comment-le-running-peut-vous-aider-auboulot-1230906.

“Course à pied ou running: Y'a-t-il débat?”, Runners.fr, http://runners.fr/course-a-pied-ourunning-y-a-t-il-debat/.

“Courses à obstacles: le phénomène Run \& Fun”, SportAixTrem, 6 July 2017, https://blog.sportaixtrem.com/courses-a-obstacles/.

"Folie du running: pourquoi on se met toutes à la course”, Femme Actuelle, 27 August 2015, https://www.femmeactuelle.fr/actu/dossiers-d-actualite/phenomene-running-23409.

"Footing, course a pied, jogging, running, tant de terminologie”, No Pain No Gain Running, 4 January 2016, http://nopainnogainrunning.com/footing-course-pied-jogging-running-tantterminologie/.

"Grand Angle Podcast”, France Inter, 7 April, 2017, https://www.franceinter.fr/emissions/grand-angle/grand-angle-07-avril-2017.

"Je cours, tu cours, elle court: le phénomène running", CNEWS, 11 October 2014, https://www.cnews.fr/loisirs/2014-10-11/je-cours-tu-cours-elle-court-le-phenomenerunning-692862.

“Jogging, footing, running”, Lalignebleue, http://www.lalignebleue.net/fr/information/45697/jogging-footing-running.

“L'évolution du coureur à pied: du jogging au running!”, Urban'r. Le Monde Est Ton Terrain De Jeu!, 23 June 2016, http://www.myurbanr.com/urbanr/conseils/running/evolutioncoureur-a-pied-jogging-running/.

“L'évolution du running depuis 2009: pratiques, marché et tendances”, FitMyRun, 7 November 2015, https://blog.fitmyrun.fr/levolution-du-running-depuis-2009-pratiques-marche-ettendances/. 
"La chaussure de running et la mode", Runner Life, 16 March 2015, http://www.runnerlife.com/2015/03/la-chaussure-de-running-et-la-mode.html.

"La course à pied, un phénomène décrypté”, Vo2Run, 27 March 2015, https://www.vo2.fr/lacourse-a-pied-un-phenomene-decrypte/6.

"La fin d'une mode, la mort du running annoncée”, Globe Runners, 19 July 2017, https://www.globe-runners.fr/la-fin-dune-mode-la-mort-du-running-annoncee/.

"La folie du running, décryptage d'une tendance”, Greenroom, 28 May 2015, https://www.greenroom.fr/74367-la-folie-du-running-decryptage-dune-tendance/.

"Le mot "running" entre dans le dictionnaire", L'Equipe, 28 May 2018, https://www.lequipe.fr/Coaching/Running/Actualites/Le-mot-running-entre-dans-ledictionnaire/905307.

"Le phénomène de la course à pied”, Sport Monde, Parabola \& Wordpress, https://sportmonde.fr/le-phenomene-de-la-course-a-pied/.

"Le phénomène running”, La Tête Au Carré, Inter France, 21 June 2016, https://www.franceinter.fr/emissions/la-tete-au-carre/la-tete-au-carre-21-juin-2016.

“Le running: une mode qui déjà s’essouffle !?”, No Pain No Gain Running, 28 September 2016, http://nopainnogainrunning.com/running-mode-sessouffle/.

"Le running fait son entrée dans le dictionnaire”, RunMotion Coach, 28 May 2018, https://runmotion.com/running-course-a-pied-dictionnaire/

“Le running, ce nouveau mode de vie!”, Eugéie Coaching, April 2015, http://letscoach.fr/lerunning-ce-nouveau-mode-de-vie-2/.

"Le running, un phénomène qui touche toutes les générations”, NewsQuest.fr, 2 November 2016, http://newsouest.fr/autres/course-pied/2016-11-02/le-running-un-phenomene-quitouche-toutes-les-generations.

"Le running: un sport tendance!”, $C M G^{+}$, cmgsportsclub.com, 4 October 2016, (https://www.cmgsportsclub.com/cmg+/running-sport-tendance/.

“L'énorme business du running”, Capital, 22 May 2015, https://www.capital.fr/economiepolitique/l-enorme-business-du-running-1040222.

"Petit dictionnaire des mots du running", Femme Actuelle, Prisma Média, 18 May 2016, https://www.femmeactuelle.fr/bien-etre/sport-fitness/fiches-sports/petit-dictionnaire-desmots-du-running-29993

“Running: comment débuter et progresser efficacement?”, Marie Claire, https://www.marieclaire.fr/,running-le-sport-tendance,819189.asp.

“Running Business: Les as du marketing se mêlent du sport!”, Running Addict, https://www.running-addict.fr/actualite/running-business-marketing-sportif/.

“Running dans la foulee d'un phenomene social”, Le Monde, 3 July 2017, https://lesclesdedemain.lemonde.fr/dossiers/running-dans-la-foulee-d-un-phenomenesocial_f-184.html.

"Running, jogging, footing, CAP”, Course à pied, May 2004, http://www.courseapied.net/forum/msg/5176.htm.

"Running: décryptage de cette passion d'enculés”, Jetenculetherese, 18 August 2015, http://www.jetenculetherese.net/societe/running-decryptage-de-cette-passion-dencules/.

"Running: le boom de la course à pied et des innovations technologiques", L'express L'expasion, 8 April 2017, https://lexpansion.lexpress.fr/actualites/1/actualiteeconomique/running-le-boom-de-la-course-a-pied-et-des-innovationstechnologiques_1897035.html 
“Running: Le Sport À La Mode”, Kinjao, 6 April 2017, http://www.kinjao.com/running-sporta-mode/.

“Running”, Académie Française, 3 April 2014, http://www.academie-francaise.fr/running.

Becker, Denis. "Le running, un phénomène de société", 3 Grand est, France Télévisions, 19 April 2015, https://france3-regions.francetvinfo.fr/grand-est/2015/04/19/le-running-unphenomene-de-societe-707995.html.

Buiatti, Marion. “Tout le monde peut-il pratiquer la course à pied?”, 20 Minutes, 22 June 2015, https://www.20minutes.fr/magazine/secoacher/sport-et-fitness/tout-le-monde-peut-ilpratiquer-la-course-a-pied-666174/.

Dewintre, Herve. “Le marché du running continue d'exploser”, FashionUnited, 13 March 2018, https://fashionunited.fr/actualite/business/le-marche-du-running-continue-dexploser/2018031215107.

Faivre, Emmanuel. "8 raisons qui me font dire que le running est devenu mode", Wanarun, 20 April 2015, https://www.wanarun.net/blog/8-raisons-qui-font-dire-que-le-running-estdevenu-mode-43987.html.

Gairin, Victoria. "Free to run: la formidable épopée de la course à pied”, 13 April 2016, https://www.lepoint.fr/pop-culture/cinema/free-to-run-la-formidable-epopee-de-la-coursea-pied-13-04-2016-2031922_2923.php.

Le Maux, Mathieu. “Les secrets du phénomène "running"”, GQ Magazine, 17 September 2013, https://www.gqmagazine.fr/lifestyle/sport/articles/les-secrets-du-phnomne-running/12723.

Leclerc, Morgan. "La course folle du running”, LSA, 7 March 2013, https://www.lsaconso.fr/la-course-folle-du-running,139646.

Niogret, Marie. “Comment le running est devenu un it-sport?”, Cosmopolitan, 2014, https://www.cosmopolitan.fr/,comment-le-running-est-devenu-un-it-sport,1906727.asp.

Palierse, Christophe. "La course à pied, un marché en plein essor", Les Echos, https://www.lesechos.fr/07/04/2017/LesEchos/22421-067-ECH_la-course-a-pied--unmarche-en-plein-essor.htm.

Pontet, Mélanie. "Pourquoi tout le monde se met au running? "Notrefamille, March 2018, https://sante-guerir.notrefamille.com/sante-a-z/pourquoi-tout-le-monde-se-met-au-runningles-tendances-sport-o340172.html.

Réby, Sébastien. “Thomas Lorblanchet défend les valeurs du trail running”, Globe Runners, 2 April 2015, https://www.globe-runners.fr/thomas-lorblanchet-defend-les-valeurs-du-trailrunning/.

Samama, Laurent David. "Mathieu Le Maux: "Le running est devenu un phénomène de société””, Les $\quad$ Inrockuptibles, 22 October 2014, https://www.lesinrocks.com/2014/10/22/livres/mathieux-maux-running-compatible-viesdurbains-11531356/.

Soya, Kévin. “Le Running: Effet de Mode ou Mode de Vie?”, Devenez Sportif, 29 May 2016, http://devenez-sportif.com/le-running-effet-de-mode-ou-mode-de-vie/.

Stadler, Sophie. "Le running, un business en or”, Le Parisien, 14 December 2016, http://www.leparisien.fr/magazine/grand-angle/le-parisien-magazine-le-running-unbusiness-en-or-16-12-2016-6455259.php.

Taleb, Sara. “Comment le running a remplacé le bon vieux jogging”, Huffpost, 4 October 2014, https://www.huffingtonpost.fr/2014/10/04/sport-running-mode-remplace-vieuxjogging_n_5918554.html. 
Zarachowicz, Weronika. “Avant de devenir une mode, le running était un acte de rébellion “, Télérama, 23 April 2016, https://www.telerama.fr/idees/avant-devenir-la-mode-le-runningetait-un-acte-de-rebellion,141150.php. 